\title{
EXPERIMENTAL INTESTINAL DYSBIOSIS IN RATS INCREASES THE PERMEABILITY OF THE BLOOD-BRAIN BARRIER AND INDUCES NEUROINFLAMMATION
}

\author{
V.G. Sergeyev, T.N. Sergeyeva \\ Udmurt State University, Izhevsk, Russia

\section{ЭКСПЕРИМЕНТАЛЬНЫЙ ДИСБИОЗ КИШЕЧНИКА У КРЫС ПОВЫШАЕТ ПРОНИЦАЕМОСТЬ ГЕМАТО-ЭНЦЕФАЛИЧЕСКОГО БАРЬЕРА И ИНДУЦИРУЕТ НЕЙРОВОСПАЛЕНИЕ}

\author{
В.Г. Сергеев, Т.Н. Сергеева \\ ФГБОУ ВО «Удмуртский государственный университет», Ижевск
}

\begin{abstract}
The mammalian intestinal microbiota consists of bacteria, fungi and viruses, including bacteriophages. This complex ecosystem has dynamic stability. It is assumed that changes in the composition of the microbiota can cause intestinal barrier dysfunction and the development of a number of pathologies, including neurodegenerative diseases accompanied by neuroinflammation. The molecular and cellular mechanisms underlying such a relationship remain poorly understood. We hypothesized that bacteriophages cause intestinal dysbiosis, increased intestinal permeability and local inflammation. Bacterial factors (endotoxins, zonulin-like proteins) and local inflammation products (cytokines, alpha-synuclein protein) can enter the circulation and increase the permeability of the blood-brain barrier (BBB), which will cause neuro-inflammation and damage to neurons. In this study, we observed an increase in BBB permeability and induction of neuroinflammation in the brain after rectal administration of a bacteriophage cocktail (Microgen, Russia). The permeability of the $\mathrm{BBB}$ was judged by the volume of the vital dye (Evans blue) emerging from the bloodstream into the brain parenchyma, and the development of the neuroinflammatory response by increasing the number of immunohistochemically stained microglial and astroglial cells.
\end{abstract}

Keywords: neurodegenerative diseases; neuroinflammation; intestinal dysbiosis; bacteriophages.

Кишечная микробиота млекопитающих состоит из бактерий, грибов и вирусов, в том числе бактериофагов. Это сложная экосистема, обладающая динамической устойчивостью. Предполагается, что изменения в составе микробиоты могут вызывать нарушение функции кишечного барьера и развитие ряда патологий, в том числе нейродегенеративных заболеваний, сопровождающихся нейровоспалением. Молекулярные и клеточные механизмы, лежащие в основе таких взаимодействий, остаются неясными. Мы предположили, что бактериофаги вызывают дисбактериоз и повышенную проницаемость кишечника, и местное воспаление. Бактериальные факторы (эндотоксины, зонулиноподобные белки) и местные продукты воспаления (цитокины, белок $\alpha$-синуклеин) могут проникать в кровоток и увеличивать проницаемость гематоэнцефалического барьера (ГЭБ), что ведет к развитию нейровоспаления и повреждению нейронов. В данном исследовании мы наблюдали увеличение проницаемости ГЭБ и индукцию нейровоспаления в головном мозге после ректального введения коктейля бактериофага (Микроген, Россия). Проницаемость ГЭБ оценивали по объему витального красителя (Эванса синий), выходящего из кровотока в паренхиму головного мозга. Развитие нейровоспалительного ответа оценивали по увеличению числу иммуногистохимически окрашенных клетки микроглии и астроглии.

Ключевые слова: нейродегенеративные заболевания; нейровоспаление; дисбиоз кишечника; бактериофаги. 